\title{
JUAL BELI COHUNG OLEH PENGRAJIN DADAK MERAK REOG PONOROGO: BOLEHKAH MENURUT ISLAM?
}

\author{
Isna Nur Fadlila \\ Fakultas Syariah UIN Maulana Malik Ibrahim Malang \\ Email: Isnafadlila@gmail.com
}

\begin{abstract}
The focus of this study is to identify cohung (peacock carcass) sale by dadak merak reog craftsman in Ponorogo and to analyse the view of Indonesian Council of Ulama (Majelis Ulama Indonesia) at Ponorogo Regency on cohung transaction. This empirical study used qualitative method. Data sources cover interview with dadak merak craftsman and MUI at Ponorogo Regency as well as documentation and literature to answer the research problem. It results in two findings. First, cohung transaction by the craftsman is done to create the fierce of dadak merak and got on agreed price. Secondly, cohung sale according to MUI at Ponorogo regency has different reasons. It is permitted because the sale practice depends on the context that is to be used not for consumption, and assumed that it is not only as transaction but also as wage. It is forbidden to buy the carcass since peacock is preserved animal.
\end{abstract}

Fokus penelitian ini adalah untuk mengetahui bagaimana praktik jual beli cohung (bangkai merak) oleh pengrajin dadak merak reog Ponorogo serta menganalisis pandangan Majelis Ulama Indonesia (MUI) Kabupaten Ponorogo terhadap praktik jual beli cohung ini. Penelitian ini merupakan penelitian empiris dengan menggunakan pendekatan kualitatif. Adapun sumber data diperoleh dari wawancara dengan pengrajin dadak merak dan MUI Kabupaten Ponorogo dan literatur untuk menjawab permasalahan penelitian. Hasil penelitian meliputi dua temuan. Pertama, praktik jual beli cohung oleh pengrajin dadak merak dilakukan untuk menghasilkan dadak merak yang berkesan galak dan diperoleh dalam keadaan kering dengan cara membeli dengan harga yang disepakati. Kedua, jual beli cohung ini menurut MUI kabupaten Ponorogo memiliki 
pendapat yang berbeda. Ulama yang membolehkan beralasan jual beli yang dilakukan tergantung pada konteksnya, yaitu apabila cohung digunakan tidak untuk dikonsumsi, dan dianggap bukan semata-mata melakukan jual beli tetapi pembayaran upah atas jerih payahnya. Ulama lain tidak membolehkan jual beli bangkai merak karena merak termasuk hewan yang dilindungi negara.

Keywords: craftsman, transaction, ulama

\section{Pendahuluan}

Jual beli adalah proses tukar menukar harta, yang dimaksud dengan harta ialah setiap benda yang manfaatannya halal walau tanpa ada keperluan, sehingga termasuk didalamnya emas, perak, gandum, garam, beras, kendaraan, bejana, buku, properti, dan lain-lain yang memiliki kemanfaatan, dan kemanfaatannya tersebut dihalalkan dalam syariat (Badri, 2008: 53). Jual beli merupakan pertukaran harta atas dasar saling rela sebagaimana dijelaskan dalam surat an Nisa ayat 29 yang menjelaskan bahwa transaksi jual beli harus berdasarkan atas dasar suka sama suka, tidak ada unsur paksaan, penipuan, dan pemalsuan yang berdampak pada dirugikannya salah satu pihak baik dari penjual maupun dari pembeli berupa kerugian materil maupun non materil. Selain itu dalam ayat tersebut juga dijelaskan bahwa dalam melaksanakan proses perpindahan hak milik atas suatu barang dari seseorang kepada orang lain, harus menggunakan jalan yang terbaik yaitu dengan jual beli, bukan dengan mencuri, merampok, menipu, dan lain sebagainya. Pada intinya jual beli merupakan salah satu cara yang dipakai manusia untuk memenuhi hajat hidupnya (Khaerunnisa dkk., 2015: 32).

Jual beli dihalalkan hukumnya, dibenarkan agama apabila memenuhi syarat-syarat yang telah ditetapkan syariat. Jual beli merupakan salah satu bentuk muamalat yang disyariatkan oleh Allah SWT. Hal ini ditegaskan dalam QS al Baqarah ayat 275 yang menjelaskan bahwa Allah telah menghalalkan jual beli yang memenuhi beberapa syarat dan rukun seperti yang telah ditetapkan-Nya kepada umat manusia. Adapun rukun-rukun yang diperlukan dalam jual beli terdiri dari aqidain (dua orang yang berakad), mahallal aqad (tempat akad), maudluul aqad (objek akad) dan syarat-syarat akad.

Terdapat hak khiyar dalam jual beli. Khiyar merupakan hak pilih bagi salah satu pihak atau kedua belah pihak yang melaksanakan transaksi jual beli dimana antara pihak penjual dan pihak pembeli sama-sama memiliki hak pilih untuk menentukan apakah mereka benar-benar akan membeli atau menjual, membatalkan dan atau menentukan pilihan di antara barang-barang 
yang ditawarkan (Elbadriati, 2014: 17). Dengan dengan hak ini terdapat ruang bagi penjual ataupun pembeli untuk memilih meneruskan atau membatalkan jual beli.

Terdapat pula pengecualian terhadap barang-barang tertentu yang diharamkan untuk diperjualbelikan baik itu dikarenakan faktor internal yaitu zat dari barang itu sendiri maupun faktor eksternal. Allah telah menerangkan keharamannya dalam QS. al Maidah ayat 3. Dalam penjelasan ayat tersebut dapat diketahui bahwa terdapat beberapa barang yang diharamkan diantaranya adalah: bangkai, darah, daging babi, daging hewan yang disembelih atas nama selain Allah, yang tercekik, terpukul, jatuh, yang ditanduk, dan yang diterkam binatang buas serta patung/berhala. Dengan demikian hal-hal yang diharamkan untuk dimakan tersebut di atas juga diharamkan pula untuk diperjualbelikan sebagaimana sabda Nabi SAW yang diriwayatkan oleh Abu Dawud dan Ahmad yang menjelaskan bahwa apabila Allah mengharamkan memakan sesuatu maka Allah juga mengharamkan untuk memperjualbelikannya.

Namun pada praktiknya pada kehidupan masyarakat masih banyak ditemui aktivitas jual beli benda-benda di atas, salah satunya adalah bangkai. Bangkai merupakan semua yang mati tanpa disembelih sesuai dengan cara yang disyariatkan agama, dalam hal ini hukumnya najis menurut kesepakatan para ulama. Hal tersebut masih dijumpai yaitu dilakukan oleh para pengrajin dadak merak reog yang menggunakan tubuh merak yang sudah mati atau disebut cohung. Salah satu pengrajin yang menggunakan cohung adalah pengrajin UD Suromenggolo Ponorogo. Cohung didapatkan oleh para pengrajin dadak merak dalam keadaan sudah dikeringkan, matinya cohung tersebut karena ditembak bukan dengan disembelih sesuai dengan syariat Islam. Cohung yang diperoleh itu kemudian digunakan sebagai bahan baku pembuatan dadak merak untuk kesenian Reog Ponorogo. Bagi para pengrajin dadak merak reog.

Cohung memiliki manfaat yaitu nilai ekonomis yang dapat menghasilkan sebuah dadak merak yang berkualitas dan memiliki nilai jual yang tinggi serta sesuai dengan pesanan yang diinginkan oleh grup-grup reog. Namun cohung merupakan salah satu hewan yang dilindungi oleh Undang-undang, karena burung merak masuk ke dalam daftar hewan yang dilindungi berdasarkan Peraturan Pemerintah No.7 Tahun 1999 Tentang Pengawetan Jenis Tumbuhan dan Satwa. Fakta inilah yang menarik untuk dikaji yaitu bagaimana praktik jual beli cohung oleh pengrajin dadak merak Reog Ponorogo dan bagaimana pandangan ulama terhadap jual beli cohung. 


\section{Metode Penelitian}

Jenis rancangan penelitian adalah penelitian empiris dengan pendekatan kualitatif (Nasution, 2008: 124; Noor, 2011: 35). Metode pengumpulan data primer adalah dengan cara indepth interview, data sekunder melalui dokumentasi jurnal-jurnal penelitian. Wawancara dilakukan kepada pengrajin UD Suromenggolo Ponorogo serta ulama di Majelis Ulama Indonesia kabupaten Ponorogo. Metode sampling menggunakan purposive sampling. Analisis dilakukan dengan mendeskrip hasil wawancara di lapangan dan menganalisisnya dengan menggunakan KHES.

\section{Pembahasan}

Ponorogo dikenal dengan sebutan kota Reog, karena di Ponorogo kesenian Reog lahir. Bahkan hingga saat ini setiap tanggal 1 Muharram atau 1 Suro, selalu diselenggarakan acara Grebeg Suro. Dalam even Grebeg Suro ini diadakan Festival Reog Nasional yang diikuti kelompok seni reog dari berbagai kota di Indonesia. Acara lain adalah Kirab Pusaka. dari Makam Batoro Katong (pendiri Ponorogo) ke Pendopo Kabupaten yang merupakan peninggalan pemimpin Ponorogo pada masa Kerajaan Wengker. Mengakhiri acara Grebeg Suro pada tanggal 1 Suro diadakan larung doa di telaga Ngebel. Even Grebeg Suro ini menjadi salah satu kalender wisata di Ponorogo dan Jawa Timur.

Reog Ponorogo adalah salah satu wujud kesenian yang muncul dari hasil budaya, yang tumbuh dan berkembang di Ponorogo. Tontonan ini berbentuk drama tari dan diiringi musik tradisional daerah setempat yang disebut gamelan. Tokoh utamanya adalah Raja Kelono Sewandono dengan patihnya yang bernama Bujang Ganong. Dua tokoh inilah yang menjadi sumber cerita kesenian Reog Ponorogo. Kesenian ini sangat akrab dan membudaya bagi warga Ponorogo dimanapun mereka berada walau mereka sampai di luar negeri sekalipun (Soemarto, 2014: 25).

Cerita kelahiran kesenian reog dimulai pada tahun saka 900. Di balik cerita tentang perjalanan Prabu Kelono Sewandono, Raja Bantarangin yang mencari calon ratu didampingi patih setia, Bujangganong. Akhirnya gadis pujaan hati telah ditemukan, yaitu Dewi Songgolangit, putri Kediri. Putri memutuskan syarat berat agar Kelono Sewandono mempersembahkan kesenian baru terlebih dahulu, dari sanalah tercipta Kesenian Reog (Hasanah, 2012: 235). 
Kesenian Reog Ponorogo terdapat dua jenis, yaitu kesenian reog pentas dan kesenian reog obyogan. Kesenian reog pentas telah mengalami modifikasi sedemikian rupa dan disesuaikan dengan kondisi zaman, dan ditampilkan di panggung kesenian. Kesenian reog pentas ini pertunjukannya memakai pakem dan berdasar lakon klana. Sedangkan kesenian reog obyogan yaitu kesenian yang hidup di pedesaan walaupun juga mengadakan pertunjukan, akan tetapi tidak memakai pakem. Pertunjukannya bisa memakai tempat di halaman-halaman rumah, perempatan atau pertigaan, jalan desa, di pelataran pekuburan (Achmadi, 2013: 114). Nilai-nilai pendidikan dalam reog Ponorogo terdiri pendidikan keimanan, pendidikan budi pekerti, pendidikan jasmani dan rohani, pendidikan kepemimpinan, pendidikan kewiraan serta pendidikan kesabaran dan optimisme (Kurnianto dkk., 2015: 244).

\section{Jual Beli Cohung Oleh Pengrajin Dadak Merak Reog Ponorogo Menurut Majelis Ulama Indonesia Kabupaten Ponorogo}

Pengrajin reog sebagai salah satu UKM di Ponorogo yang memiliki keunikan tersendiri yang menghasilkan seperangkat reog dengan segala atributnya juga telah banyak membantu mendorong pertumbuhan ekonomi dan mengurangi pengangguran. Selain itu pengrajin reog juga sangat berperan terhadap kesenian Reog Ponorogo yang membawa nama Ponorogo hingga dikenal masyarakat Indonesia hingga manca negara (Kristiyana, 2017: 150).

Data yang diperoleh dari lapangan menunjukkan bahwa terjadi akad jual beli cohung antara penjual dan pengrajin dadak merak yang merupakan kerajinan peralatan kesenian Reog Ponorogo yang telah menjadi budaya bangsa Indonesia. Cohung adalah bangkai burung merak yang nantinya digunakan sebagai bahan baku pembuatan dadak merak Reog Ponorogo. Dadak merak merupakan topeng yang digunakan dalam tarian Reog Ponorogo. Jual beli dilakukan dengan cara penjual datang ke tempat pengrajin dengan membawa cohung, dan pengrajin akan membeli sesuai kebutuhannya. Jika pengrajin membutuhkan maka akan dibeli sesuai dengan harga yang telah ditawarkan (Nugroho, wawancara: 25 Maret 2017).

Cohung diperoleh pengrajin dalam keadaan sudah dikeringkan yang meliputi postur luar burung merak yang terdiri kulit, sayap, kaki, kepala dan bagian dalamnya sudah tidak ada seperti jeroan dan daging. Sementara bulu yang digunakan sebagai bahan baku pembuatan dadak merak diimpor dari India. Perbedaan menggunakan cohung asli dan tidak adalah jika menggunakan cohung asli menghasilkan dadak merak yang lebih mahal, dan pemakainya 
merasa bahwa memakai dadak merak tersebut terkesan lebih sangar (galak) (Nugroho, wawancara: 25 Maret 2017).

Data yang diperoleh tersebut dianalisis melalui pendapat ulama Majelis Ulama Indonesia Kabupaten Ponorogo. Dari beberapa ulama memiliki pendapat yang berbeda-beda dengan memiliki landasan atau alasan yang sama-sama kuat. Diantara pendapat-pendapat yang dikemukakan oleh ulama Majelis Ulama Indonesia Kabupaten Ponorogo adalah sebagai berikut:

Pertama, pendapat Achmad Munir yang mengemukakan bahwa segala sesuatu tergantung pada konteksnya, dalam kasus jual beli cohung tersebut diperbolehkan dalam fiqh karena tidak untuk dikonsumsi. Achmad Munir menjelaskan bahwa dalam fiqih Islam terdapat dua macam hal ketika kita membicarakan perihal bangkai yaitu bangkai dari binatang yang halal atau suci dan yang haram atau najis. Kalau bangkai binatang yang haram dan najis maka sudah selesai artinya tidak ada upaya-upaya lagi untuk dimanfaatkan contohnya babi, anjing, dan sebagainya. Kalau binatang yang suci atau halal misalnya ada kambing mati maka kulitnya masih bisa disamak maka masih bisa dipakai, dan merak masuk bagian yang suci karena termasuk jenis burung.

Hal tersebut sesuai dengan hadits Rasulullah SAW bahwa kulit bangkai yang telah disamak maka ia menjadi suci, terdapat dalam hadits sebagai berikut: Jika kulit telah disamak, maka ia telah suci (HR. Muslim).

Cohung dalam konteks bangkai tersebut postur tubuhnya dan bagian dalamnya pun sudah dibersihkan memang dapat dikatakan bangkai merak namun orang yang menjual pun tidak bermaksud untuk menjual bangkai merak begitu pula pembelinya. Tapi yang menjadi kontrak akadnya adalah hiasan postur tubuh dalam ornamen seninya maka menurut pendapat ulama adalah boleh karena menjualnya tidak digunakan untuk konsumsi tapi dalam bentuk karya seni.

Barang yang najis ada konteksnya tersendiri yaitu ketika untuk dimakan, jika untuk hiasan tidak ada kaitannya dengan halal dan haram tapi memang jika dikatakan najis memang termasuk najis dalam konteks memegangnya. Karena dalam hal tersebut lebih ditekankan pada bulu dan postur tubuh luarnya saja maka diperbolehkan. Pengharaman sesuatu ada konteksnya, dalam hal ini adalah untuk dimakan sebagaimana firman Allah SWT:

"Diharamkan bagimu (memakan) bangkai, darah, daging babi, dan (daging) hewan yang disembelih bukan atas (nama) Allah, yang tercekik, yang dipukul, yang jatuh, yang ditanduk, dan yang diterkam binatang buas, kecuali yang sempat kamu sembelih. Dan (diharamkan pula) yang disembelih untuk berhala. Dan (diharamkan pula) mengundi nasib dengan azlam (anak panah), (karena) itu suatu perbuatan fasik. Pada 
hari ini orang-orang kafir telah putus asa untuk (mengalahkan) agamamu, sebab itu janganlah kamu takut kepada mereka, tetapi takutlah kepada-Ku. Pada hari ini telah Aku Sempurnakan agamamu untukmu, dan telah Aku Cukupkan nikmat-Ku bagimu, dan telah Aku Ridai Islam sebagai agamamu. Tetapi barangsiapa terpaksa karena lapar bukan karena ingin berbuat dosa, maka sungguh, Allah Maha Pengampun, Maha Penyayang." (QS. al Maidah: 3).

Dari ayat tersebut bangkai diharamkan untuk dimakan, jika tidak untuk dikonsumsi maka diperbolehkan. Pendapat ini sejalan dengan pendapat mazhab Zahiri dan mazhab Hanafi yang memperbolehkan mengambil manfaat dari barang najis yang tidak untuk dikonsumsi. Mereka melihat kenyataan yang berkembang selama ini telah berlangsung jual beli terhadap sejumlah barang yang dikategorikan najis seperti kotoran ternak yang bermanfaat bagi tanaman (Nurkholis, 2009: 71).

Lebih lanjut Achmad Munir mengemukakan apabila dalam hukum negara tidak diperbolehkan maka fiqh pun mengikutinya karena ketaatan kepada ulil amri juga bagian dari ketaatan beragama sebagaimana kaidah ushul fiqh: Keputusan pemimipin ada kemaslahatan umat. Oleh karena itu fiqh pun mengikutinya karena di dalam kebijakan tersebut terdapat kemaslahatan (Achmad Munir, wawancara: 30 Maret 2017).

Kedua, Imam Sayuthi Farid mengemukakan pendapat bahwa jual beli tersebut tekanannya pada pihak pengrajin membeli dari pihak penjual berasal dari Tuban, maka perlu adanya hilah atau rekayasa artinya boleh, apabila tekanannya pada membeli uang jasa. Jadi tidak semata-mata akad jual beli, tetapi pemberian jasa atas kepayahan dia yang mencari dan membawa cohung tersebut. Jadi jual beli itu boleh apabila status jual belinya menjadi di hilah atau tidak semata-mata membeli barang itu tetapi memberi jasa kepada orang yang mencarinya. Karena juga demi kemasalahatan tertentu yakni pengembangan budaya (Imam Sayuthi Farid, wawancara: 20 april 2017).

Hal yang mendasari pendapat Imam Sayuthi Farid, adalah melalui adanya hilah. Definisi dari hilah itu sendiri adalah strategi atau siasat hukum dengan melakukan tindakan yang disyariatkan ataupun tidak untuk menggugurkan suatu hukum atau mengubahnya menjadi hukum yang lain dengan maksud atau tujuan yang negatif ataupun positif. Artinya strategi tersebut dilakukan dengan tujuan yang tidak sesuai dengan syariat yakni membenarkan kebatilan atau strategi yang dilakukan mempunyai tujuan-tujuan yang benar sesuai dengan syariat yakni menetapkan yang haq dan menolak yang batil (Wahidi, 2009: 12). Hilah dalam konteks jual beli tersebut yang dimaksud oleh Imam 
Sayuthi Farid adalah dengan cara menganggap bahwa jual beli tersebut bukan semata-mata melakukan jual beli saja tetapi sebagai pembayaran upah atas kerja kerasnya atau jerih payah dalam mendapatkan cohung dan dalam membawanya sampai kepada pengrajin.

Ketiga, Muhsin mengemukakan pendapat bahwa ada dua hal yang perlu dicatat dalam permasalahan tersebut yaitu (1) Hewan tersebut terlindungi. (2) Mati dalam kondisi diburu dan tidak disembelih jadi sesuatu yang tidak halal. Jadi ada dua hal yang menjadi catatan di atas yaitu jual belinya tidak sah, secara normatif saja di dalam fiqh. Jadi di dalam fiqh menjelaskan apabila sesuatu itu memperolehnya itu tidak boleh maka memberikan kepada orang lain juga tidak boleh. Dari sisi itu maka tidak sah, cuma masalahnya jika hal ini untuk budaya seni, problemnya yaitu apakah budaya itu bertentangan dengan budaya yang lain. Melestarikan merak itu juga budaya maka dilindungi, melestarikan reog juga budaya. Itu bisa menjadi boleh kalau sudah mencapai pada taraf dharurat. Kalau memang sudah tidak ada upaya lain dan merupakan suatu keharusan. Namun jika tidak sampai taraf dharurat maka tidak boleh. (Muh Muhsin, wawancara: 17 April 2017). Kaidah fiqih yang menjadi dasar pendapat Muh Muhsin adalah apa yang haram mengambilnya berarti haram pula memberikannya.

Mengemukakan mengenai kemaslahatan dan kemudharatan jual beli cohung, Muh Muhsin mengutarakan bahwa, melestarikan merak juga ada kemaslahatan, jika tidak ada merak tidak berdampak langsung pada kehidupan manusia. Di sisi lain, keberadaan merak menunjukkan kekayaan fauna dan alam. Begitu juga dengan reog, bila tidak ada juga tidak apa-apa dan kalaupun ada reog maka menjadikan kebudayaan lebih berwarna-warni (Muh Muhsin, wawancara: 17 April 2017). Berdasarkan alasan-alasan yang dikemukakan oleh Muh. Muhsin selaku ketua komisi fatwa hukum dan perundang-undangan maka dapat disimpulkan bahwa jual beli cohung diperbolehkan jika sudah mencapai taraf dharurat.

Berdasarkan data yang diperoleh jika dianalisis dengan Kompilasi Hukum Ekonomi Syariah (KHES) dapat diuraikan sebagai berikut:

Pertama, rukun dari jual beli yang pertama adalah pihak-pihak, yaitu pihak-pihak yang terikat dalam perjanjian jual beli terdiri atas penjual, pembeli, dan pihak lain yang terlibat dalam perjanjian tersebut (Pasal 57 KHES). Dalam jual beli tersebut terdapat penjual dan pembeli, dilakukan oleh pihak-pihak yang telah memenuhi syarat yaitu berakal, cakap hukum, tamyiz, serta dilakukan oleh orang yang berbeda yaitu antara pemasok cohung sebagai penjual dan 
pihak pengrajin sebagai pembeli (Ghazely, 2010: 71).Dalam pasal 23 KHES disebutkan bahwa pihak-pihak yang berakad adalah orang perseorangan, kelompok orang, persekutuan atau badan usaha. Orang yang berakad harus cakap hukum, berakal dan tamyiz. Sehingga dapat dikatakan bahwa jual beli cohung tersebut telah memenuhi rukun yang pertama.

Kedua, rukun yang kedua adalah objek. Objek jual beli terdiri atas benda yang berwujud maupun yang tidak berwujud, yang bergerak maupun tidak bergerak, dan yang terdaftar maupun tidak terdaftar (Pasal 58 KHES). Dalam Kompilasi Hukum Ekonomi Syariah dijelaskan mengenai syarat objek yang diperjualbelikan, terdapat pada pasal 76 dan 78 yaitu: (1) Barang yang dijualbelikan harus ada. (2) Barang yang dijualbelikan harus dapat diserahkan. (3) Barang yang dijualbelikan harus berupa barang yang memiliki nilai/ harga tertentu. (4) Barang yang dijualbelikan harus halal. (5) Barang yang dijualbelikan harus diketahui oleh pembeli. (6) Kekhususan barang yang dijualbelikan harus diketahui. (7) Penunjukan dianggap memenuhi syarat kekhususan barang yang dijualbelikan apabila barang itu ada di tempat jual beli. (8) Sifat barang yang dapat diketahui secara langsung oleh pembeli tidak memerlukan penjelasan lebih lanjut. (9) Barang yang dijual harus ditentukan secara pasti pada waktu akad.

Selanjutnya dijelaskan jual beli dapat dilakukan terhadap: (1) Barang yang terukur menurut porsi, jumlah, berat, atau panjang, baik berupa satuan atau keseluruhan. (2) Barang yang ditakar atau ditimbang sesuai jumlah yang telah ditentukan, sekalipun kapasitas dari takaran atau timbangan tidak diketahui. (3) Satuan komponen dari barang yang sudah dipisahkan dari komponen lain yang telah terjual (Suhendi, 2016: 67-68).

Dalam transaksi jual beli cohung oleh pengrajin jika dikaitkan dengan syarat objek jual beli diatas perlu digaris bawahi pada poin (4) barang yang diperjualbelikan harus halal. Dalam pasal 26 KHES dijelaskan bahwa akad tidak sah apabila bertentangan dengan: (1) Syariat Islam (2) Peraturan perundangundangan (3) Ketertiban umum (4) Kesusilaan.

Jika dikaitkan dalam transaksi jual beli tersebut objeknya adalah cohung yang dapat dikategorikan sebagai bangkai, namun bangkai yang dimanfaatkan adalah bagian postur tubuh luarnya yang telah dikeringkan. Dalam syariat Islam kulit bangkai yang telah disamak maka ia menjadi suci, serta bangkai dalam kasus tersebut dengan tujuan untuk tidak dikonsumsi, maka diperbolehkan sehingga tidak bertentangan dengan syariat Islam. 
Namun dalam peraturan perundang-undangan, cohung termasuk daftar hewan yang dilindungi. Cohung (merak) merupakan salah satu hewan yang dilindungi oleh undang-undang, hal ini terdapat pada lampiran PP No. 7 Tahun 1999 Tentang Pengawetan dan Jenis Tumbuhan dan Satwa, dalam lampiran PP tersebut disebutkan bahwa merak merupakan hewan yang dilindungi. Sehingga dapat dikatakan bahwa jual beli belum memenuhi syarat tersebut karena bertentangan dengan undang-undang. Namun demikian, penggunaan cohung adalah dalam rangka pelestarian budaya Indonesia.

Selain cohung yang termasuk objek pertukaran adalah harga yang diberikan dalam bentuk uang. Para ulama fikih mengemukakan syarat-syarat harga barang sebagai berikut: (1) Harga yang disepakati kedua belah pihak harus jelas jumlahnya. (2) Boleh diserahkan pada waktu akad, sekalipun secara hukum seperti pembayaran dengan cek dan kartu kredit. Apabila harga barang itu dibayar kemudian (berhutang) maka waktu pembayarannya harus jelas. (3) Apabila jual beli itu dilakukan dengan saling mempertukarkan barang, maka barang yang dijadikan nilai tukar bukan barang yang diharamkan oleh shariah seperti babi dan khamr, karena kedua jenis benda ini tidak bernilai menurut shariah.

Dalam bagian ketujuh Kompilasi Hukum Ekonomi Syariah (KHES) pasal 79 dan 80 dijelaskan mengenai hak yang berkaitan dengan harga dan barang setelah akad bai', diantaranya: (1) Penjual mempunyai hak untuk bertasharruf terhadap harga barang yang dijual sebelum menyerahkan barang tersebut. (2) Apabila barang yang dijual itu adalah sebuah barang yang tidak bergerak, pembeli dapat langsung menjual barang yang tidak bergerak itu kepada pihak lain sebelum penyerahan barang tersebut. (3) Ketentuan sebagaimana tersebut pada ayat (2) tidak berlaku bagi barang yang bergerak. Transaksi yang dilakukan pengrajin dengan penjual cohung dilakukan sesuai harga yang telah disepakati yang telah ditawarkan oleh penjual, yang dibayarkan pada saat itu di tempat tinggal pengrajin.

Ketiga, kesepakatan, dalam alam Kompilasi Hukum Ekonomi Syariah, dijelaskan mengenai kesepakatan antara para pihak yang melakukan jual beli, dalam pasal 59 dijelaskan bahwa: kesepakatan dapat dilakukan dengan tulisan, lisan, dan isyarat. Kesepakatan sebagaimana dimaksud memiliki makna hukum yang sama. Pada pasal 60 dan 61 KHES dijelaskan kesepakatan dilakukan untuk memenuhi kebutuhan dan harapan masing-masing pihak, baik kebutuhan hidup maupun pengembangan usaha. Ketika terjadi perubahan akad jual beli akibat perubahan harga, maka akad terakhir yang dinyatakan berlaku. 
Kesepakatan antara penjual dan pembeli dalam Kompilasi Hukum Ekonomi Syariah (KHES) dijelaskan sebagai berikut: (1) Penjual dan pembeli wajib menyepakati nilai objek jual beli yang diwujudkan dalam harga. (2) Penjual wajib menyerahkan objek jual beli sesuai dengan harga yang telah disepakati. (3) Pembeli wajib menyerahkan uang atau benda yang setara nilainya dengan objek jual beli. (4) Jual beli terjadi dan mengikat ketika objek jual beli diterima pembeli, sekalipun tidak dinyatakan secara langsung. (5) Penjual boleh menawarkan penjualan barang dengan harga borongan, dan persetujuan pembeli atas tawaran itu mengharuskannya untuk membeli keseluruhan barang dengan harga yang disepakati. (6) Pembeli tidak boleh memilah-milah benda dagangan yang diperjualbelikan dengan cara borongan dengan maksud membeli sebagiannya saja. (7) Penjual dibolehkan menawarkan beberapa jenis barang dagangan secara terpisah dengan harga yang berbeda (Suhendi, 2016: 67-68).

Dalam transaksi jual beli cohung dilakukan sesuai kesepakatan antara penjual dan pembeli yang dilakukan di tempat tinggal pembeli, dengan cara penjual datang ke tempat tinggal pembeli dengan membawa barang (cohung) beserta harga yang ditawarkan. Dalam transaksi tersebut terdapat kerelaan antara kedua belah pihak, ketika pihak pembeli (pengrajin) sedang memerlukan cohung maka pengrajin akan membelinya sesuai dengan harga yang telah ditawarkan penjual dan telah disepakati keduanya.

\section{Simpulan}

Majelis Ulama Indonesia Kabupaten Ponorogo memiliki perbedaan pendapat mengenai status kebolehan jual beli cohung, ada yang mengatakan diperbolehkan dan ada yang tidak memperbolehkan. Jual beli cohung diperbolehkan dalam fiqh karena tidak untuk dikonsumsi namun sebaiknya tidak dilakukan mengingat hewan merak tersebut dilindungi oleh negara. Pendapat lain yang memperbolehkan adalah karena hilah yaitu dengan cara menganggap bahwa jual beli tersebut bukan semata-mata melakukan jual beli saja tetapi sebagai pembayaran upah atas kerja kerasnya atau jerih payah dalam mendapatkan cohung dan dalam membawanya sampai kepada pengrajin. Sedangkan pendapat yang tidak memperbolehkan adalah karena barang tersebut tidak disembelih sesuai syariat Islam dan dilindungi oleh undang-undang, dan bisa menjadi boleh jika sudah mencapai taraf dharurat, 


\section{Daftar Pustaka}

Achmadi, Asmoro. 2013. Pasang Surut Dominasi Islam Terhadap Kesenian Reog Ponorogo. Analisis. Vol XIII No 1.

Anonim. 2009. Kompilasi Hukum Ekonomi Syariah. Jakarta: Kencana Prenada Media Group.

Badri, Muhammmad Arifin bin. 2008. Sifat Perniagaan Nabi. Bogor: Pustaka Darulilmi.

Elbadriati, Baiq. 2014. Rasionalitas Penerapan dalam Jual Beli Islam. Iqtishaduna. Vol. 5.

Ghazely, Abdul Rahman \& Ghufron Ihsan, dkk. 2010. Fiqh Muamalat. Jakarta: Kencana.

Hasanah, Uswatun. 2012. "Bathara Katong, Reog Ponorogo, dan Penyebaran Islam di Jawa." Ibda' Jurnal Kebudayaan Islam. Vol 10 No. 2.

Khaerunnisa, Ana Selvia \& Eef Saefullah. 2015. Jual Beli Lelang Perspektif Islam. Al Musthafa Vol. 3 No. 2.

Kristiyana, Naning. 2017. Dinamika Usaha Pengrajin Reog Ponorogo. Jurnal Riset Akuntansi dan Bisnis Airlangga. Vol 2 No. 1: 149-164.

Kurnianto, Rido \& Niken Lestarini. 2015. Nilai-nilai Edukasi Dalam Seni Reog Ponorogo. el-Harakah.Vol 17 No. 2: 240-258.

Nasution, Bahder Johan. 2008. Metode Penelitian Ilmu Hukum. Bandung: CV Mandar Maju.

Noor, Juliansyah. 2011. Metodologi Penelitian: Skripsi, Tesis, Disertasi dan Karya Ilmiah. Jakarta: Kencana Prenada Media Group.

Nurkholis. 2009. Tinjauan Hukum Islam terhadap Jual Beli Ayam Tiren (Studi Kasus Penjual Ayam di Pasar Rejomulyo Semarang). Skripsi. Semarang: IAIN Walisongo Semarang.

Salim, Abu Malik Kamal bin As Sayid. 2007. Shahih Fikih Sunnah Lengkap Jilid 1. Jakarta: Pustaka Azzam.

Soemarto. 2014. Menelusuri Perjalanan Reog Ponorogo. Ponorogo: CV. Kotareog Media. 
Suhendi, Hendi. 2016. Fiqh Muamalah. Jakarta: PT Raja Grafindo Persada.

Wahidi, Ahmad. 2009. Manipulasi Hukum Islam Kajian tentang Latar Belakang dan Substansi Hukum. Malang: UIN-Maliki Press. 